\title{
Pengaruh Pemberian Ransum dengan Kualitas Berbeda Terhadap Profil Darah, Produksi Susu dan Pertambahan Bobot Badan Sapi Perah
}

\author{
A. Hanifa \\ Jurusan Peternakan, Fakultas Pertanian, Universitas Sebelas Maret \\ Jl. Ir. Sutami 36 A, Kentingan, Surakarta \\ Email:aqni_hanifauns@yahoo.co.id
}

\section{INTISARI}

Penelitian bertujuan untuk mengetahui profil darah, produksi susu dan pertambahan bobot badan sapi perah akibat pemberian ransum dengan kualitas berbeda. Penelitian menggunakan 15 ekor sapi perah Peranakan Friesian Holstein (PFH) laktasi yang dibagi menjadi 3 kelompok perlakuan dan 5 ulangan, tiga perlakuan ransum tersebut adalah : 1) TI (PK 12\% dan TDN 65\%); 2) T2 (PK 14\% dan TDN 70\%)dan 3) T3 (PK 16\% dan TDN 75\%).

Hasil penelitian menunjukkan bahwa rataan konsumsi BK untuk perlakuan TI, T2 dan T3 berturut-turut adalah sebagai berikut 8,$59 ; 10,03$ dan $10,94 \mathrm{~kg} / \mathrm{hari}$ $(\mathrm{P}<0,01)$. Rataan konsumsi PK untuk perlakuan TI, T2 dan T3 masing-masing adalah 1,$06 ; 1,44$ dan $1,71 \mathrm{~kg} /$ hari $(\mathrm{P}<0,01)$, sedangkan rataan konsumsi TDN untuk perlakuan T1, T2 dan T3 berturut-turut adalah sebagai berikut : 5,52: 6,86 dan $8,02 \mathrm{~kg} /$ hari $(\mathrm{P}<0,01)$. Rataan kadar Hemoglobin $(\mathrm{Hb})$ untuk perlakuan $\mathrm{T} 1, \mathrm{~T} 2$ dan T3 masing-masing adalah 10,$21 ; 11,18$ dan 10,44 g/dl $(\mathrm{P}>0.05)$, sedangkan rataan jumlah eritrosit untuk perlakuan $\mathrm{T} 1, \mathrm{~T} 2$ dan $\mathrm{T} 3$ berturut-turut adalah sebagai berikut : 3,$37 ; 3,73$ dan 3,48 juta $/ \mathrm{mm}^{3}(\mathrm{P}>0.05)$. Rataan produksi susu untuk perlakuan T1, T2 dan T3 masing-masing adalah 8,12; 11,29 dan 13,42 1/hari $(\mathrm{P}<0,05)$. Rataan pertambahan bobot badan ( $\mathrm{pbb}$ ) sapi untuk perlakuan $\mathrm{T} 1, \mathrm{~T} 2$ dan T3 berturut-turut adalah sebagai berikut : 81,66; 117,71 dan 320,00 g/hari $(\mathrm{P}>0,05)$.

Berdasarkan hasil penelitian di atas dapat disimpulkan bahwa pemberian ransum dengan level kualitas PK dan TDN ransum yang tinggi (PK 16\% dan TDN $75 \%$ ) menunjukkan konsumsi ransum (BK, PK dan TDN) serta produksi susu yang lebik baik dibandingkan dengan perlakuan lainnya.

Kata kunci kualitas ransum, konsumsi ransum, profil darah, produksi susu, pertambahan bobot badan, sapi perah laktasi

\section{The Effect of Different Dietary Quality of Diets on Blood Profile, Milk Yield and Liveweight Gain of Dairy Cows}

\section{ABSTRACT}

An experiment was conducted to study blood profile, milk yield and liveweight gain of dairy cows as affected by dietary different quality of diets. The experiment used 15 lactating PFH were assigned into three treatments of diets and 
five replication, three treatments of diets were : 1) T1 (CP 12\% dan TDN 65\%);2) T2 (CP 14\% dan TDN 70\%) dan 3) T3 (CP 16\% dan TDN 75\%).

The results of this experiment showed that the average of dry matter (DM) intake on $\mathrm{Tl}, \mathrm{T} 2$ and $T 3$ treatments were 8,59;10,03 and 10,94 $\mathrm{kg} / \mathrm{d}$, respectively $(P<0,01)$. The average of crude protein intake $(C P)$ on T1, T2 and T3 treatments were 1,$06 ; 1,44$ and $1,71 \mathrm{~kg} / \mathrm{d}(P<0,01)$, also the average of TDN intake on T1, T2 and $T 3$ treatments were 5,$52 ; 6,86$ and $8,02 \mathrm{~kg} / \mathrm{d}(P<0,01)$. The average of Hemoglobin $(\mathrm{Hb})$ concentration on T1, T2 and T3 treatments were 10,21: 11,18 and $10,44 \mathrm{~g} / \mathrm{dl}(P>0,05)$, also the average of eritrosit value on TI, T2 and T3 treatments were 3,37; 3,73 and 3,48 million $/ \mathrm{mm}^{3 ;}$, respectively $(P>0,05)$. The average of milk yield on T1, T2 and T3 treatments were 8,12;11,29 and 13,42 l/d $(P<0,05)$. The average of liveweight gain on TI, T2 and T3 treatments were 81,66; 117,71 and $320,00 \mathrm{~g} d(\mathrm{P}>0,05)$.

The conclusions of this research was the highest level of $C P$ and "I'DN in diets (CP 16\% and TDN 75\%) showed that feed intake (DM, CP and TDN) and milk yield gave the best than other treatments. Different dietary quality of diets altered significant on feed intake (DM, CP and TDN) and milk yield, but the treatments did not affect on liveweight gain, Fib and eritrosit concentration.

Key words : diets quality, feed intake, blood profile, milk yield, liveweight gain, dairy cows

\section{PENDAHULUAN}

Sub sektor peternakan memegang peranan penting dalam pemenuhan kebutuhan akan protein hewani khususnya dari susu. Susu merupakan salah satu sumber protein yang selalu mengalami peningkatan permintaan setiap tahun seiring dengan pertambahan jumlah penduduk, kemajuan ekonomi dan peningkatan kesadaran masyarakat akan pentingnya susu bagi kehidupan. Kebutuhan susu untuk konsumsi masyarakat Jawa Tengah pada tahun 2004 mencapai 112 iuta $\mathrm{kg}$ atau 115 juta 1, sedangkan ketersediaan susu segar \pm 78 juta $\mathrm{kg}$ atau 80 juta 1. Produksi susu di Jawa Tengah baru dapat mencapai \pm $44 \%$ dari permintaan konsumsi masyarakat Jawa Tengah dan sisanya dipenuhi melalui pasokan susu dari luar daerah ataupun dengan cara mengimport (Dinas Peternakan Propinsi Jawa Tengah, 2005). Jumlah dan komposisi susu dipengaruhi oleh $30 \%$ faktor genetik dan sisanya dari faktor non genetik, adapun beberapa faktor non genetik yang mempengaruhi produksi susu adalah masa laktasi, umur sapi, frekuensi pemerahan, kualitas dan kuantitas ransum.

Rendahnya produktivitas sapi perah di Indonesia salah satunya dipengaruhi oleh potensi fisiologis tubuh di dalam proses metabolisme. Proses metabolisme tubuh sapi perah meliputi proses transportasi nutrisi dan proses biosintesis nutrisi menjadi produk berupa energi, daging dan susu. Proses transportasi sangat ditentukan oleh aliran darah terutama peran eritrosit dan $\mathrm{Hb}$, sedangkan proses biosintesis ditentukan oleh potensi kerja sel dalam jaringan yang juga dipengaruhi oleh kualitas dan kuantitas pasokan nutrisi yang berasal dari ransum. Selama periode laktasi, sapi perah mengalami proses anabolisme dan katabolisme tubuh sehingga memberikan dampak fluktuasi terhadap pembentukan eritrosit, $\mathrm{Hb}$, 
produksi susu dan PBB. Oleh karena itu, perlu diketahui sampai sejauh mana pembentukan eritrosit, $\mathrm{Hb}$, produksi susu dan PBB sapi perah laktasi dipengaruhi olah pemberian ransum dengan kualitas berbeda. Soelistyono (1976) menyatakan bahwa kualitas konsentrat perlu diperhatikan dalam menyusun ransum sapi perah laktasi dan hal ini ditentukan oleh kandungan energi dan proteinnya. Menurut Sutardi (1981), kebutuhan ransum sapi perah tergantung oleh kebutuhan hidup pokok dan produksi. Kebutuhan BK sapi perah tergantung oleh jenis ternak, ukuran tubuh dan keadaan fisiologis ternak. Energi merupakan tenaga bagi proses hidup dan produksi ternak. Kekurangan energi bagi sapi perah yang sedang laktasi dapat menurunkan bobot badan dan produksi susu, bila terjadi defisiensi energi yang berkelanjutan maka dapat mengganggu proses reproduksinya. Pemberian ransum yang berkualitas baik bertujuan untuk memperbaiki kondisi tubuh sehingga akan terjadi proses regenerasi sel-sel sekretorik ambing dan dapat meningkatkan aktivitas sel sekretorik kelenjar ambing yang pada akhirnya membawa produksi susu pada laktasi berikutnya meningkat (Purboyo, 1991).

Ganong (1980) menyatakan bahwa pembentukan eritrosit ditandai dengan penurunan ketersediaan oksigen dalam jaringan dan sel yang akan merangsang ginjal melepaskan enzim eritrogenin $(\mathrm{REF}=$ Renal Eritropoeitin Faktor $)$ untuk mengaktilkan eritropoietinogen (prekursor eritropoeitin yang dihasilkan oleh hati). Globulin merupakan protein plasma yang dihasilkan oleh hati. REF menyebabkan stem sel tertentu dalam sumsum tulang diubah menjadi proeritoblast. Perkembangan selanjutnya proeritoblast berubah menjadi normoblast. Brown dan Dellmann (1989) menambahkan bahwa eritrosit berfungsi mengangkut oksigen ke jaringan dan mengembalikan karbon dioksida dari jaringan ke paru-paru. Eritrosit mempunyai komposisi 60 sampai $70 \%$ air, 28 sampai $35 \% \mathrm{Hb}$ serta bahan-bahan organik dan anorganik lainnya. Jumlah eritrosit dipengaruhi oleh suhu lingkungan, ketinggian tempat, kebuntingan, laktasi dan kualitas ransum. Proses pembentukan eritrosit membutuhkan tercukupinya bahanbahan seperti suplai protein, zat besi, cobalt dan tembaga dalam jumlah yang cukup. Darah adalah cairan tubuh yang tersusun atas sel-sel cairan interseluler yang disebut plasma. Darah mempunyai unsur seluler terdiri atas eritrosit (sel-sel darah merah), leukosit (sel-sel darah putih) dan trombosit (keping darah). Ransum merupakan bahan yang penting untuk metabolisme darah sebab dibutuhkan protein, vitamin dan mineral untuk pembentukan sel darah merah (Frandson, 1992).

\section{MATERI DAN METODE}

Materi yang digunakan adalah 15 ekor sapi perah PFH periode laktasi kedua dengan kisaran bobot badan 350 sampai $400 \mathrm{~kg}(\mathrm{CV}=11,50 \%)$. Perlakuan disusun dalam Rancangan Acak Lengkap (RAL) dengan 3 perlakuan dan 5 ulangan. Ransum yang dicobakan terdiri atas : T1 (PK 12\% dan TDN 65\%); T2 (PK 14\% dan TDN 70\%) dan T3 (PK $16 \%$ dan TDN 75\%). Ransum terdiri atas hijauan berupa rumput gajah dan konsentrat dengan imbangan 55: 45 . Pemberian ransum perlakuan dilakukan selama 10 minggu dengan seminggu masa adaptasi, ransum diberikan dua kali dalam sehari dan air minum diberikan secara ad libitum. Susunan komposisi ransum yang diberikan selama penelitian tersaji pada Tabel 1 . 
Tabel 1. Susunan Komposisi Ransum yang Diberikan Selama Penelitian

\begin{tabular}{|c|c|c|c|c|}
\hline \multirow[b]{2}{*}{ Jenis Ransum } & \multicolumn{4}{|c|}{ Komposisi Ransum } \\
\hline & $\mathrm{BK}$ & PK & SK & TDN \\
\hline & & ----- & -- & ------- --. \\
\hline Rumput Gajah & 23,95 & 14,50 & 33,11 & 58,38 \\
\hline Ransum T1 & 80,70 & 9,00 & 18,11 & 73,07 \\
\hline Ransum T2 & 87,00 & 14,30 & 14,90 & 84,18 \\
\hline Ransum T3 & 88,30 & 17,30 & 11,54 & 95,32 \\
\hline
\end{tabular}

Sumber : Laboratorium Teknologi Pengolahan Hasil Pertanian, Fakultas Teknologi Pertanian UGM, Yogyakarta

Parameter yang diamati adalah sebagai berikut: 1) konsumsi ransum (BK, PK dan TDN) dalam satuan $\mathrm{kg}$, pengukuran dilakukan setiap hari dengan menimbang jumlah ransum yang diberikan dan dikurangi sisa pakan pada keesokan harinya, selanjutnya untuk mengetahui kandungan BK, PK dan TDN dilakukan analisis proksimat; 2) Kadar $\mathrm{Hb}(\mathrm{g} / \mathrm{dl})$ dan jumlah eritrosit (juta/ $/ \mathrm{mm}^{3}$ ), pengukuran dilakukan setiap 2 minggu; 3) Produksi susu (1), pengukuran dilakukan setiap hari dengan menjumlahkan hasil pemerahan pada pagi dan sore hari; 4) Pertambahan bobot badan harian (g/hari), penimbangan dilakukan setiap 2 minggu serta menghitung selisih bobot badan akhir dan awal dibagi dengan jarak waktu penimbangan.

\section{HASIL DAN PEMBAHASAN}

\section{Konsumsi Ransum}

Pengaruh perlakuan terhadap konsumsi ransum (BK, PK dan TDN) ditunjukkan pada Tabel 2.

Tabel 2 menunjukkan bahwa konsumsi BK ransum antara perlakuan T1, T2 dan T3 berbeda sangat nyata $(\mathrm{P}<0,01)$, hal itu disebabkan oleh kadar PK ransum pada T2 dan T3 (14\% dan 16\%) lebih tinggi daripada T1 (12\%) sehingga perlakuan ransum T2 dan T3 mampu meningkatkan palatabilitas ternak yang pada akhirnya akan meningkatkan konsumsi BK ransum.

Tabel 2. Pengaruh Perlakuan Terhadap Konsumsi Ransum (BK, PK dan TDN) pada Perlakuan T 1, T2 dan T3

\begin{tabular}{cccc}
\hline \hline & \multicolumn{3}{c}{ Jenis Perlakuan } \\
\cline { 2 - 4 } & T1 & T2 & T3 \\
Parameter yang & ----------------- & \\
diamati & & $10,03^{\mathrm{b}}$ & $10,94^{\mathrm{c}}$ \\
BK & $8,59^{\mathrm{a}}$ & $1,44^{\mathrm{b}}$ & $1,71^{\mathrm{c}}$ \\
PK & $1,06^{\mathrm{a}}$ & $6,86^{\mathrm{b}}$ & $8,02^{\mathrm{c}}$ \\
TDN & $5,52^{\mathrm{a}}$ &
\end{tabular}

- Superskrip huruf kecil yang berbeda pada baris yang sama menunjukkan berbeda sangat nyata $(\mathrm{P}<0,01)$ 


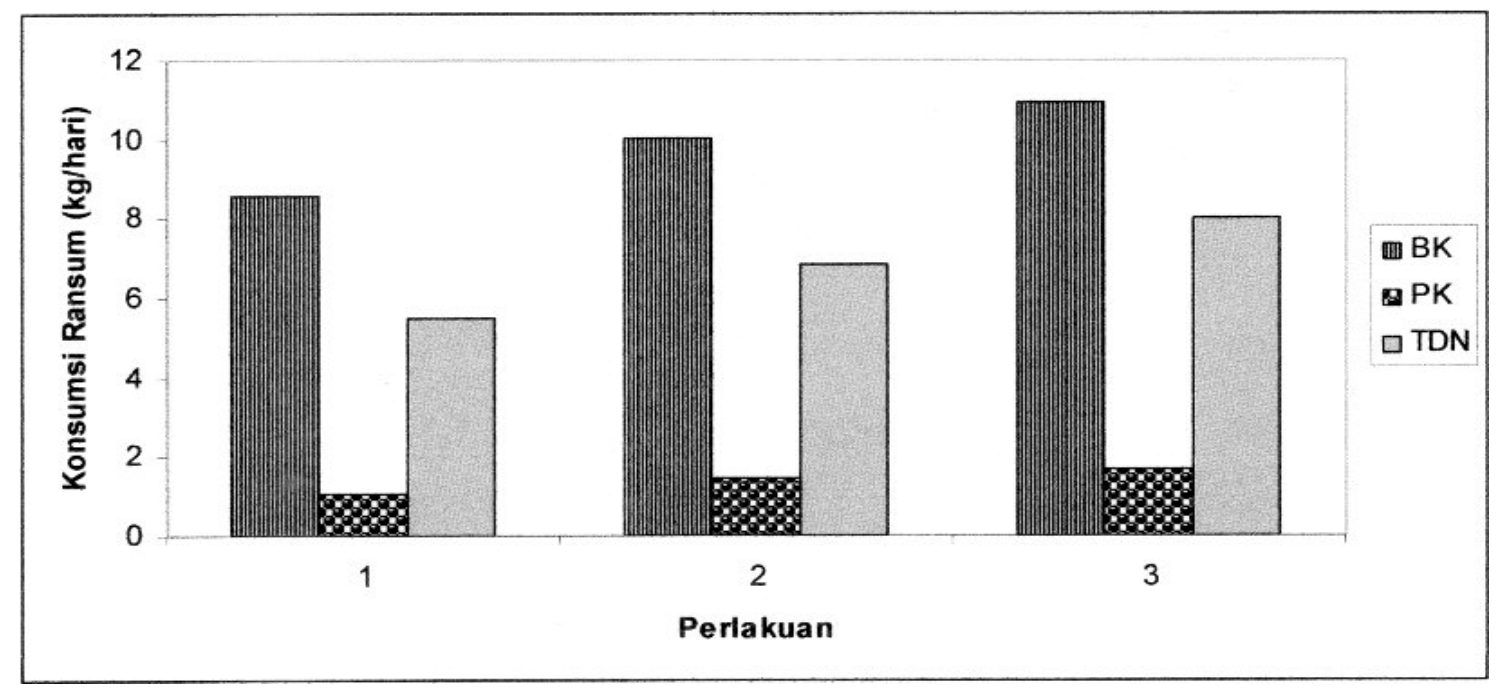

Ilustrasi 1.Diagram Batang Konsumsi Ransum (BK, PK dan TDN) pada Perlakuan $\mathrm{T} 1, \mathrm{~T} 2$ dan $\mathrm{T} 3$

Konsumsi PK ransum antara perlakuan ransum TI, T2 dan T3 menunjukkan berbeda sangat nyata $(\mathrm{P}<0,01)$, hal tersebut disebabkan oleh meningkatnya konsumsi BK ransum yang secara otomatis mengakibatkan konsumsi PK ransum juga meningkat. Konsumsi BK ransum pada perlakuan ransum T2 dan T3 (10,03 dan 10,94 $\mathrm{kg} /$ hari) lebih tinggi daripada T1 $(8,59$ $\mathrm{kg}$ /hari). Konsumsi T'DN ransum antara perlakuan ransum T1, T2 dan T3 menunjukkan berbeda sangat nyata $(\mathrm{P}<0,01)$, hal itu disebabkan TDN ransum yang dikonsumsi ditentukan oleh BK ransum yang dikonsumsi, artinya semakin tinggi konsumsi $\mathrm{BK}$ ransum maka semakin tinggi pula konsumsi TDN ransum.

\section{Profil Darah}

Pengaruh perlakuan terhadap kadar $\mathrm{Hb}$ dan jumlah eritrosit ditunjukkan pada Tabel 3.

Jumlah eritrosit dan kadar $\mathrm{Hb}$ antara perlakuan ransum $\mathrm{T} 1, \mathrm{~T} 2$ dan $\mathrm{T} 3$ menunjukkan tidak berbeda nyata $(\mathrm{P}>0,05)$, hal ini disebabkan salah satu bahan pembentuk eritrosit (protein) diduga lebih banyak digunakan untuk proses biosintesis susu sehingga PK ransum yang terkonsumsi pada perlakuan ransum T2 dan T3 yang digunakan untuk pembentukan eritrosit diduga sama dengan perlakuan ransum TI. Eppard et al. (1997) menyatakan bahwa pembentukan eritrosit berkaitan dengan proses biosintesis produk yang dihasilkan oleh ternak. Kadar $\mathrm{Hb}$ berkorelasi positif terhadap jumlah eritrosit (dalam kondisi normal) sehingga meningkat atau menurunnya jumlah eritrosit akan disertai meningkat atau menurunnya kadar $\mathrm{Hb}$.

Hasil percobaan Andriani (1997), pada induk domba bunting yang ditingkatkan level PK ransum dari 11\% menjadi $18 \%$ tidak memberikan peningkatan yang berbeda nyata terhadap kadar $\mathrm{Hb}$ pada anaknya baik jantan maupun henna. Hal tersebut berarti bahwa pembentukan eritrosit dan kadar $\mathrm{Hb}$ mempunyai faktor pembatas, meskipun salah satu prekursornya berasal dari suplai protein, namun terdapat kerja suatu enzim eritrogenin (REF = Renal Eritropoeitin Faktor) yang mengatur pembentukan eritrosit dan $\mathrm{Hb}$ itu sendiri 
serta dapat disimpulkan bahwa sebaik apapun kualitas dan kuantitas ransum yang diberikan pada ternak tidak memberikan peningkatan yang nyata terhadap jumlah eritrosit dan kadar $\mathrm{Hb}$.

Tabe1 3. Pengaruh Perlakuan Terhadap Kadar Hb dan Jumlah Eritrosit pada Perlakuan T1, T2 dan T3

\begin{tabular}{lccc}
\hline \hline \multirow{2}{*}{ Parameter yang diamati } & \multicolumn{3}{c}{ Jenis Perlakuan Ransum } \\
\cline { 2 - 4 } & & T2 & T3 \\
\hline a. Kadar $\mathrm{Hb}(\mathrm{g} / \mathrm{dl})$ & $10,21^{\mathrm{a}}$ & $11,18^{\mathrm{a}}$ & $10,44^{\mathrm{a}}$ \\
a. Jumlah Eritrosit $\left(\mathrm{juta} / \mathrm{mm}^{3}\right)$ & $3,37^{\mathrm{a}}$ & $3,73^{\mathrm{a}}$ & $3,48^{\mathrm{a}}$ \\
\hline
\end{tabular}

- Superskrip huruf kecil yang sama pada baris yang sama menunjukkan tidak berbeda nyata $(\mathrm{P}>0,05)$

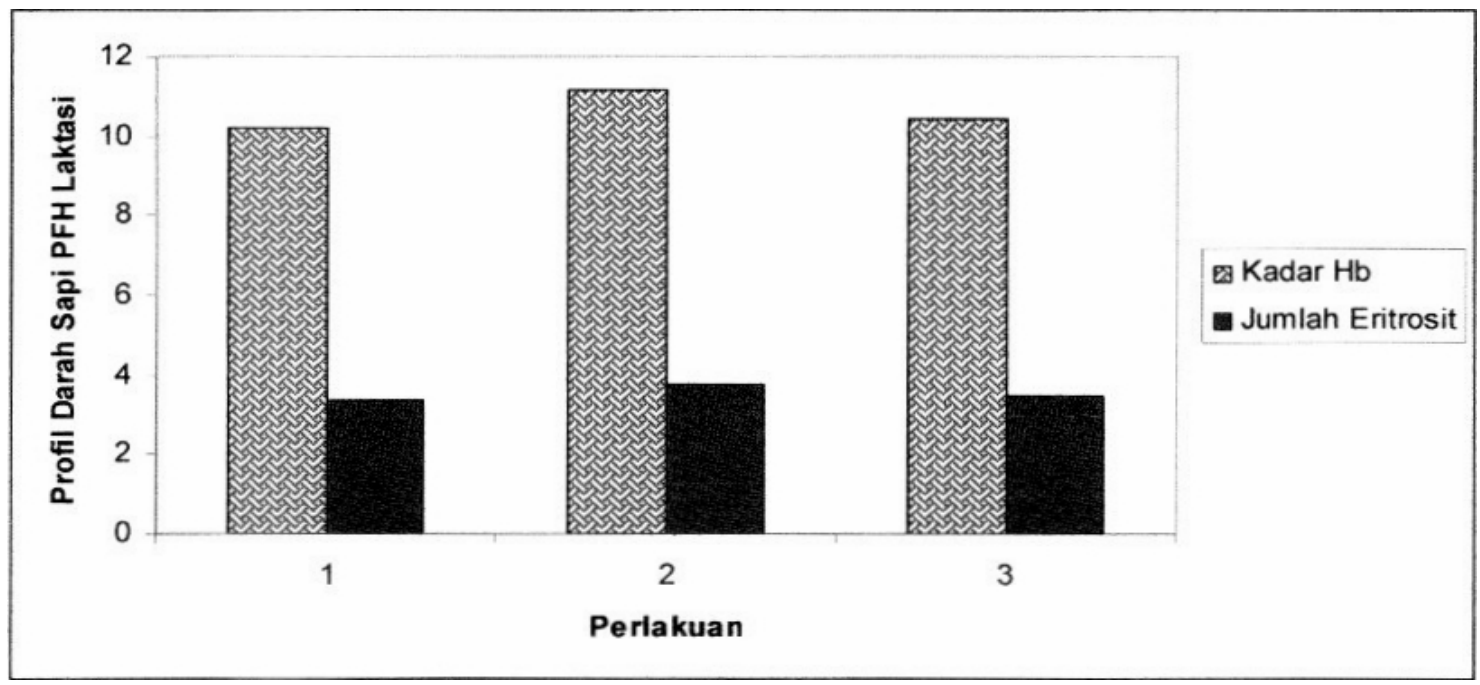

Ilustrasi 2. Diagram Batang Profil Darah (Kadar Hb dan Jumlah Fritrosit) pada Perlakuan T1, T2 dan T3

\section{Produksi Susu dan Pbb}

Pengaruh perlakuan terhadap produksi susu dan Pbb ditunjukkan pada Tabel 4.

Tabel 4 menunjukkan bahwa produksi susu antara perlakuan T1, T2 dan T3 berbeda nyata $(\mathrm{P}<0,05)$, hal ini disebabkan prekursor komponen dan kualitas susu ditentukan oleh kualitas (Tabel 1) dan kuantitas ransum (Tabel 2) yang dikonsumsi (BK, PK dan TDN) juga berbeda nyata. Kenyataan tersebut sesuai dengan pernyataan Barton et al. (1996) bahwa peningkatan level PK ransum dari $13 \%$ menjadi $20 \%$ meningkatkan produksi susu dari $25,80 \pm 0,391$ menjadi 27,17 $\pm 0,491$. Agus (1997) menambahkan bahwa tipe konsentrat sumber energi dalam ransum sapi perah dapat mempengaruhi produksi dan komponen susu.

Tabel 4 menunjukkan bahwa $\mathrm{Pbb}$ antara perlakuan T1, T2 dan T3 tidak berbeda nyata $(\mathrm{P}>0,05)$, hal ini disebabkan sapi perah yang sedang laktasi akan mengorbankan tubuhnya (proses katabolisme) untuk berproduksi, hal ini dapat dilihat produksi susu pada perlakuan ransum T2 dan T3 $(11,291$ 
dan 13,42 1) yang lebih tinggi daripada T1 $(8,12$ 1) maka energi sapi perah yang sedang laktasi diduga lebih banyak digunakan untuk produksi susu, sehingga tidak memberikan peningkatan nyata terhadap pertambahan bobot badan sapi perah laktasi.

Tabel 4. Pengaruh Perlakuan Terhadap Produksi Susu dan Pbb pada Perlakuan T1, T2 dan T3

\begin{tabular}{lccc}
\hline \hline \multirow{2}{*}{ Parameter yang diamati } & \multicolumn{3}{c}{ Jenis Perlakuan Ransum } \\
\cline { 2 - 4 } & $\mathrm{T} 1$ & $\mathrm{~T} 2$ & $\mathrm{~T} 3$ \\
\hline a. Produksi Susu ( 1/hari) & $8,12^{\mathrm{a}}$ & $11,29^{\mathrm{b}}$ & $13,42^{\mathrm{c}}$ \\
b. Pbb (g/hari) & $81,66^{\mathrm{a}}$ & $117,71^{\mathrm{a}}$ & $158,57^{\mathrm{a}}$ \\
\hline
\end{tabular}

- Superskrip huruf kecil yang berbeda pada baris yang sama menunjukkan berbeda nyata $(\mathrm{P}<0,05)$

- Superskrip huruf kecil yang sama pada baris yang sama menunjukkan tidak berbeda nyata $(\mathrm{P}>0,05)$

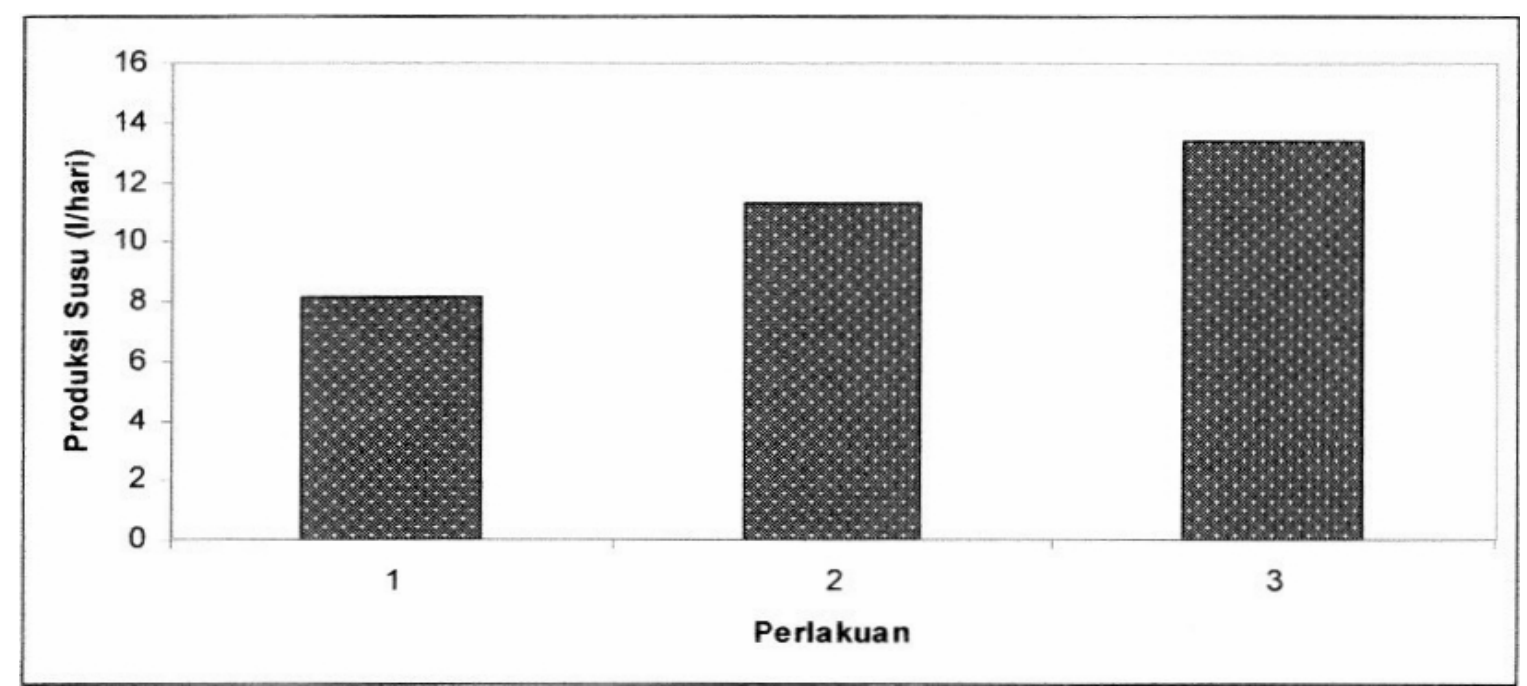

Ilustrasi 3. Diagram Batang Produksi Susu pada Perlakuan TI, T2 dan T3

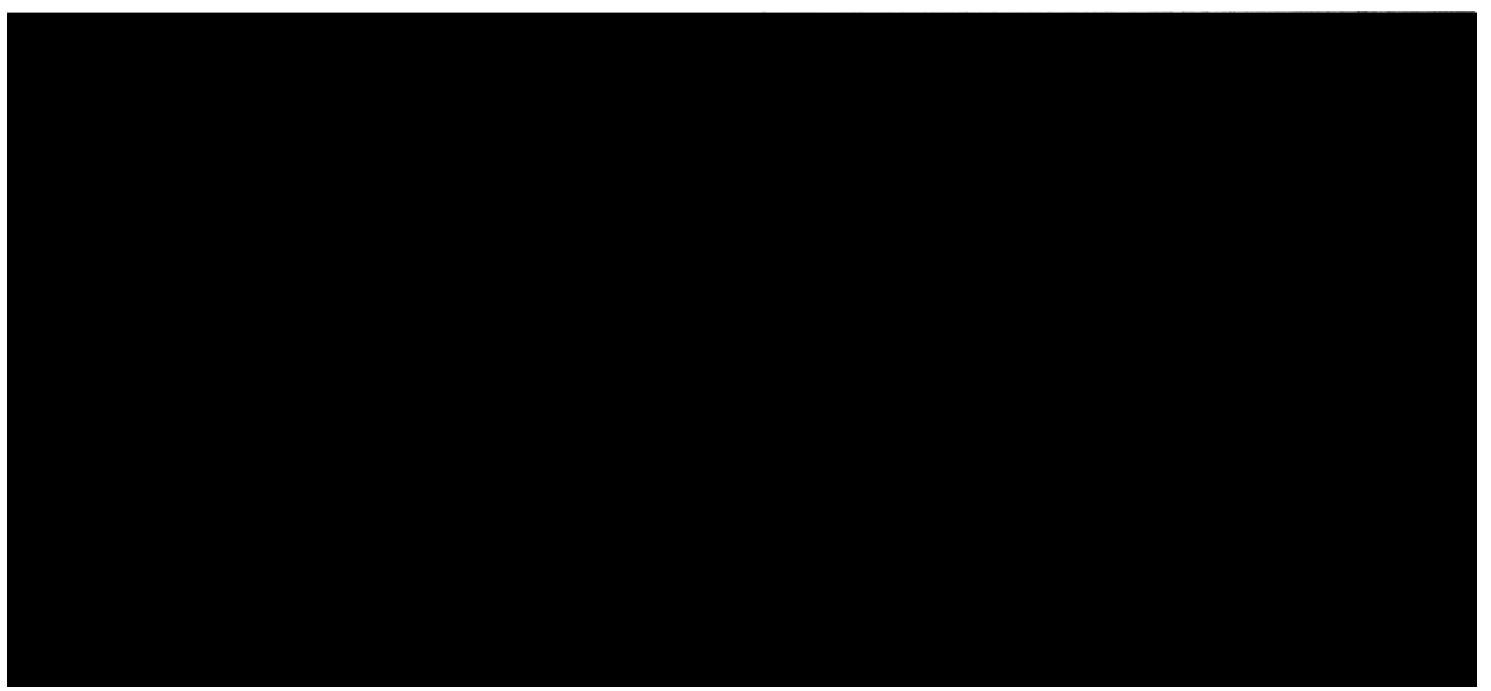

Ilustrasi 4. Diagram Batang Pbb Sapi PFH Laktasi pada Perlakuan TI, T2 dan T3 
Kenyataan hasil penelitian tersebut meskipun tidak berbeda nyata, namun masih sependapat dengan penelitipeneliti terdahulu diantaranya, Simandjuntak (1977) yang menyatakan bahwa pemberian tingkat konsentrat (1 $\mathrm{kg}$ konsentrat untuk 1,5 $\mathrm{kg}$ produksi susu) dapat meningkatkan pbb sapi laktasi sampai 53,30 g/hari. Dilanjutkan oleh Komagiri dan Erdman (1992) bahwa peningkatan level PK ransum dari 16 ke $19 \%$ dapat meningkatkan bobot badan dari 1149 ke 1293 g/hari, ditambahkan lagi oleh Sudjatmogo (2000) bahwa sapi perah yang di PMSG dan mendapatkan ransum yang kadar PK nya ditingkatkan dari 10 ke $15 \%$ ternyata $\mathrm{Pbb}$ nya naik sampai $56,33 \mathrm{~g} /$ hari.

\section{KESIMPULAN}

Pemberian ransum dengan kualitas berbeda berupa perbedaan level PK sampai $16 \%$ dan TDN sampai $75 \%$ pada sapi perah laktasi dapat meningkatkan secara nyata terhadap konsumsi ransum (BK, PK dan TDN) serta produksi susu, namun tidak meningkatkan secara nyata pada jumlah eritrosit dan kadar $\mathrm{Hb}$ serta pertambahan bobot badan.

\section{DAFTAR PUSTAKA}

Agus, A. 1997. Pengaruh tipe konsentrat somber energi dalam ransom sapi perah berproduksi tinggi terhadap produksidan komposisi susu. Bull. Peternakan 21(1): 45-54.

Andriani, F. 1997. Tampilan kadar hemoglobin, hematokrit induk serta anak jantan dan betina saat lahir akibat pemberian kualitas ransom yang berbeda pada induk domba bunting. Fakultas Pertanian Universitas Djuanda, Bogor. (Skripsi Sarjana Peternakan)

Barton, B.A., H.A. Rosario, G. W. Anderson, B.P. Grindle dan D.J.
Carrot. 1996. Effect of dietary crude protein, breed, parity and health status on the fertility of dairy cows. J. of Dairy Sci. 79: 2225-2236.

Brown, M.E. dan H.D. Dellmann. 1989. Histologi Veteriner. Edisi ketiga. Universitas Indonesia, Jakarta.

Dinas Petemakan Propinsi Jawa Tengah. 2005. Statistik Peternakan Propinsi Jawa Tengah Tahun 2005. Dinas Peternakan Propinsi Jawa Tengah, Ungaran.

Eppard, P.J., T.C. White, R.H. Sorbet, M.G. Weiser, W.J. Cole, G.F. Hartnell, R.L. Hintz, G.M. Lanza, J.L. Vicini dan R.J. Collier. 1997. Effect of exogeneous somatrotopin on hematological variables of lactating cows on their offsring. J. of Dairy Sci. 80: 15821591.

Frandson, R.D. 1992. Anatomi dan Fisiologi Ternak. Gadjah Mada University Press, Yogyakarta. (Diterjemahkan oleh B. Srigandono dan K. Praseno)

Ganong, W.F. 1980. Fisiologi Kedokteran (Review of Medical Physiology). Edisi kesembilan. CV. EGC, Jakarta. (Diterjemahkan oleh A. Dharma)

Purboyo, B. 1991. Hubungan Antara Periode Kering Kandang Dengan Produksi Susu Laktasi Berikutnya Pada Sapi Perah di BPT Baturaden. Program Pascasarjana Universitas Gadjah Mada, Yogyakarta. (Tesis Magister Petemakan)

Soelistyono, H.S. 1976. Dasar-dasar Ilmu Makanan Ternak. Fakultas Peternakan Universitas Diponegoro, Semarang. (Tidak dipublikasikan)

Sutardi, T. 1981. Sapi Perah dan Pemberian Makanannya. Fakultas Petemakan Institut Pertanian Bogor, Bogor. 